Article

\title{
The Modelling of Roof Installation Projects Using Decision Trees and the AHP Method
}

\author{
Augustinas Maceika 1,t, $\neq$, Andrej Bugajev $2, *, t, \ddagger(\mathbb{D})$ and Olga R. Šostak $2, t, \ddagger$ \\ 1 The Faculty of Mechanics, Vilnius Gediminas Technical University, Sauletekio ave. 11, \\ LT-10223 Vilnius, Lithuania; augustinas.maceika@vgtu.lt \\ 2 The Faculty of Fundamental Sciences, Vilnius Gediminas Technical University, Sauletekio ave. 11, \\ LT-10223 Vilnius, Lithuania; olgaolgaregina@yahoo.com \\ * Correspondence: zvex77777@gmail.com \\ + Current address: Sauletekio ave. 11, LT-10223 Vilnius, Lithuania. \\ $\ddagger$ These authors contributed equally to this work.
}

Received: 15 November 2019; Accepted: 14 December 2019; Published: 19 December 2019

\begin{abstract}
In this work, the process of roofing projects' execution is considered. The proper analysis of this process is important to optimise the behaviour of a project's participants and to perform risk evaluation. The main result of this work is methodology, which can be used to optimise a project owner's decisions and potentially can be applied for risk control or integrated into expert systems. This methodology includes the application of a decision tree and AHP (analytic hierarchy process) method to perform the modelling for roof installation project selection. In the proposed approach, a decision tree describes the process with nodes representing the states of a project. The tree includes the decision on whether to sell the project results or not, which requires the estimation of the subjective opinion of the project owner. These subjective values are used in the decision tree leaves. We propose to perform this estimation with the AHP method and describe how to do it in this paper. A particular example was considered. The proposed methodology was applied to that case, and all details of the process and results are provided. Using the proposed methodology, the adapted version of a specific, current situation model of project participants' behaviours can be formed, allowing one to make the most efficient decisions in the light of the existing constraints. The application of results can increase the investor protection and contribute to the general sustainability of investments.
\end{abstract}

Keywords: decision tree; analytic hierarchy process; dynamic programming; sustainable investment; project participants' behaviour; roof installation projects

\section{Introduction}

\subsection{The Background of the Research}

In this research we consider roof installation projects, which can be defined as the organised, temporary processes of constructing, renovating, refurbishing, etc., a roof. We investigate such projects from the point of view of project owner (investor); thus, the profit is the goal function in optimisation problems that arise as a part of the this research. The results and the methodology presented in this work can be applied to some other similar building projects; however, we focus on this particular case to overview the complete set of the properties that are typical for such types of projects.

The construction business is often associated with risky and contentious situations and their solutions. Investors should avoid risky situations and the damage that they can cause. Many construction projects include roof installation, replacement or repair processes. There is a need for tools that will give a clear picture of the projects' implementation situation and find out 
about the results of the various options. One of the tools, selected to investigate by the authors of this article, is the decision tree, which can be used to analyse the behaviours of the participants in the selection and implementation of the roof installation projects and to make the most efficient decisions. The second tool is the analytic hierarchy process, which is used to provide a decision tree based on subjective opinion data from the roof installation project owner.

Human beings need to make decisions based on several different criteria in order to solve many problems around themselves [1]. When assessing roofing projects, it is important to choose a set of criteria that will be relevant to decision-making, taking into account the project life cycle stages. One of the important criteria is length of construction time. The results of cost performance (deviation) investigation with respect to the length of construction time implies that cost performance is project specific and it is difficult to conclude based on certain attributes; the most important thing is to consistently evaluate and have a closer look on cost development and establish a learning platform to overcome unexpected changes [2].

Other criteria can be related to the social costs of construction. Attempts to investigate the social costs of building constructions in urban residential areas are still insufficient due to probable difficulties and complexities of including the third parties; however, in the decision making process for construction projects, apart from economic sense of it, decision-makers need to be provided with other useful information: analytical and procedural assessments to comment on the convenience of the expected environmental impacts once the proposed project is implemented, and a social assessment to find out if the consequences of developing the proposed project are socially acceptable [3].

Additional costs may arise from conflicts with third parties. To analyse this situation, stochastic dynamic programming can be used. That enables a broad analysis of the dependencies between the optimal investor's strategy and the probabilities that third parties will select a certain strategy [4]. One of the implementations of dynamic programming is the decision tree approach, which is useful because this method enables the analysis of the step-by-step project execution process, including evaluation of the behaviour of the participants. It is also suitable for analysing the possible choice alternatives.

For project evaluation, it is important to select appropriate methodology. Advancements (framework and methodology for evaluating project competencies and project key performance indicators (KPIs); relationship determined between the different project competencies and grouping them using factor analysis; applying of advanced modelling techniques through the joint application of prioritised fuzzy aggregation, factor analysis, and fuzzy neural networks (FNNs) to identify the relationship between the different project competencies and project KPIs) should allow construction practitioners to identify and monitor the relationships between evaluation criteria of project competencies' and project KPIs throughout the project lifecycle to ensure better project performance [5].

One of proposed multiple criteria techniques is based on the decision tree for determining the project, using various types of criteria for comparisons of alternate strategies [6]. When a single strategy is the best with respect to all criteria, the problem is trivial; however, in most situations it is faced with conflicting criteria. A common approach to address such a problem consists of two phases: determining a set of efficient strategies and selecting the best of those strategies [6].

\subsection{The Relationship to the Agency, Stakeholder and Stewardship Theories}

Next, in order to establish the relationships between the main participants of the roof installation projects, agency, stakeholder and stewardship topics will be overviewed.

For decision making it is important to find interaction the mechanisms between the project owner (principal) and the managers, consultants and supervisors (agents), taking into account environmental conditions.

A social psychological perspective on agency relations and solution mechanisms reveals that each agency problem (each solution of an agency problem) becomes a problem of social power to the principal (agent) if she (he) changes her (his) beliefs, attitudes, or behaviour as a result of the action, 
or presence of the agent (principal) [7]. An analysis of one agency problem after the other revealed that in all situations in which an agency problem exists, the principal possesses quantitatively more bases of power than the agent; in the hidden intentions and hidden action-situations, she additionally possesses those power bases with a broader range; agency theory assumes implicitly an asymmetry in power in favour of the principal [7].

The nature of relationship between the client and agent has been presented as the model of "one servant of two masters" based on to the triangular relationship between the client, the construction company and its project manager [8].

In this field of research, an agent-based simulation that conceptualises insights from behavioural economics to increase understanding of price formations in housing markets was used, and it was found that the model produces the most favourable results when there are agents with extremely myopic expectations in the market and when other agents mimic them [9].

Analysis of stakeholders' impacts on the creation and successful implementation of roof installation projects is the part of decision tree development. For this reason, a number of works about the methodology and results devoted to stakeholder theory were analysed.

In the work of this field, through the application of focus group study, 13 stakeholder groups were identified across the lifecycles of net zero energy homes, including home buyers, sales personnel, financial institutions, developers, designers and drafting personnel, estimators, project managers/coordinators, regulators, superintendents, inspectors, trades/suppliers, net zero energy home occupants and warranty staff [10]. According to another source, eleven groups of stakeholders were identified; namely, employees, customers, shareholders, creditors, suppliers and partners, environment and resources agencies, local communities, government, competitors and non-governmental organisations [11]. In this work, corporate social responsibility (CSR) indicators were extracted for each performance issue by analysing environment, health and safety, human resources, supply chain management, customers and communities, governance and ethics aspects of construction enterprises [11].

The value of good stakeholders' management is visible from the work, where the findings from the interviews emphasised the need for a "proactive" stakeholder management approach which takes into account both the views of primary and secondary stakeholders, and there, through building internal capabilities for secondary stakeholder management, organisations have to recognise the importance of creating the right vision for major public infrastructure and construction projects and delivering not just assets but bringing extra value either at national, regional or local level [12].

The effects of underlying collaboration between designers and contractors were examined and the results show that the best means to promote the collaboration is "reducing collaboration costs", followed by "increasing the collaboration benefits" and "decreasing the loss caused by a lack of collaboration" [13].

In one article, off-site manufacturing stakeholders' business information was analysed and 59 sustainability perceptions were identified, covering the social, environmental and economic sustainability dimensions. Among them, "high quality" and a "customer-focused approach and customisation" were most valued [14].

In the other article, relevant governance criteria are introduced which can be used to judge on extents to which stakeholder participation effectively contributes to increased urban sustainability. They include legitimacy, accountability, representation, responsibility and transparency; moreover, a literature review was conducted, from which outcomes are presented across three categories of stakeholder participation—stakeholder based initiatives, government based initiatives and science based initiatives, outcomes which have briefly been assessed with respect to the governance criteria [15].

For our investigation, the model for analysing stakeholder conflicts in urban redevelopment projects is important too, because some roofing projects can be related to renovation. The proposed stakeholder salience theory and Pawlak's conflict theory are useful, and generated 
an action scheme that mitigates stakeholder conflicts and maximises project benefits [16]—which can be taken into account during roofing project developments.

The people themselves and the environment they live in, their homes and neighbourhoods, if located around the building construction zones, are exposed to adverse impacts of the construction activities [3]. In return, people react via altering their daily routine to resolve or alleviate the exposed disruptions to their common life patterns and the cost of this reaction is defined as the social costs associated with building construction projects. As the definition of social cost implies, there are costs caused by constructions that are to be paid by the third parties [3].

The cradle to cradle $(\mathrm{C} 2 \mathrm{C})$ theory propounds that environmental impact reduction can provide a positive economic impulse to stakeholders; current sustainability strategies focus on reducing the negative environmental impacts of buildings. The systems theory of $\mathrm{C} 2 \mathrm{C}$, however, aims at a positive impact; this could suggest that the state-of-the-art becomes inadequate when adopting $\mathrm{C} 2 \mathrm{C}$ as a strategy for improvement, focusing on closed or continuous materials, and energy and water cycles [17].

Stewardship theory concept provides that the managers of different organisations participating in roof installation projects must act responsibly, taking into account stakeholders needs.

In the field of stewardship theory, an opinion given is that understanding the institutional framing, underpinnings and logic of mega projects can provide the key to successful delivery of solutions in water, transportation, energy, communications, health, education and a variety of related sectors, through the development of best practices for building social, organisational and political legitimacy that can enhance the security and stability of the role that such projects play in an increasingly interconnected world [18].

Organisational support, customer pressure and regulatory pressure have significant positive effects on the adoption of environmental practices in construction projects; moreover, environmental practices have a positive effect on the environmental and economic performances of construction firms. This result may be even more important for managers of construction firms to convince stakeholders that investments in environmental practices will not reduce competitiveness and may even increase profitability while simultaneously benefiting the environment [19].

Local governments, community-based organisations, foundations, neighbourhood and other advocacy groups, construction companies, investors, commercial banks, tenants and their brokers, ecologists, media and unions, all are the participants of the city development and city stakeholders, and they should be able to create feasible projects which generate benefits and reduce the risk involved in urban development [20].

Following the analysis of the literature and the existing construction practice situation, the main parties involved in the selection and implementation of roof installation projects were identified and are presented in Figure 1.

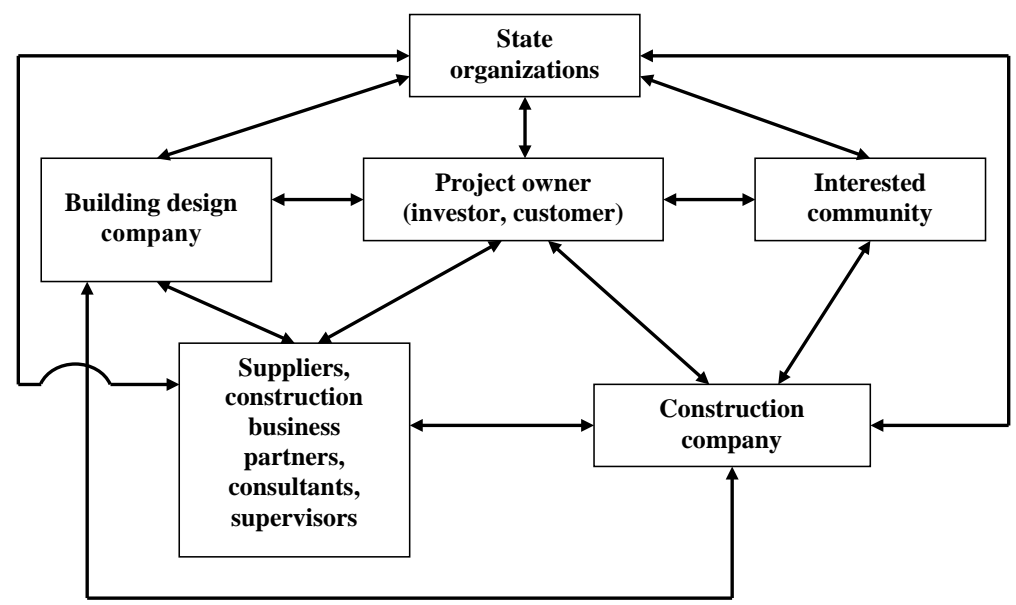

Figure 1. The main participants in the selection and implementation of the roof installation projects. 
The project owner (investor, customer) is connected with other participants who are interested in the results of a roofing project's implementation. For successful project creation and implementation, the project owner must initiate a number of processes to ensure that the communication network between the participants in the process will be developed.

\subsection{The Importance of Roofing Projects}

As new construction develops and the renovation process is under way, one of the most complex and responsible building elements-the roof-requires additional attention and effort to achieve a more sustainable state. In studies of whole-building lifecycle assessments, it has been mentioned that the most significant components added during renovation are the roof access floors, and new windows, while the new construction scenario was overwhelmingly burdened by manufacturing intensive structural (concrete and steel) and envelope components (brick and terracotta walls) [21]. The roof renovation process can be important for energy-saving changes and the social network or professionals can influence the decision to implementing the energy renovation measures [22]. As measures on both occupant behaviour and physical improvement have influences on energy saving to various extents, effective renovation strategies should be developed by combining both building technologies and behavioural changes [23].

\subsection{The Problem Statement}

We discussed the information about connections between participants, possible events along with their probabilities and monetary and time costs during those events. However, in raw form, such information is not suitable for direct analysis. Thus, there is a need for software layer between the human and raw data.

The end goal of the investor's activity is profit. The process during which the profit is achieved can be described as Markov decision process. Such a process can be described as a decision tree where the nodes represent states (events) which are connected between by edges representing the transitions between those states. It might look like some classical approaches, such as typical Markov decision process modelling methods, might solve that problem and was already developed a long time ago (see, for example, [24]). However, to apply classical Markov decision process modelling, the values for all states must be given. In the considered case the values describing the final states depend on:

- The costs of all previous states.

- The accumulated costs due to time, passed during some of the previous states; i.e., some time-dependent project costs.

- The evaluation of the project value that must be properly addressed using multi-criteria evaluation techniques.

The goal of this research was to provide a methodological approach for roofing projects evaluation. When there are decision nodes, first, an optimal investor behaviour strategy must be formed. Thus, this brings forth the optimisation problem that is needed to be addressed. In this article, it is done by taking the profit value as a goal function. Two abstraction levels of the problem can be considered:

- Evaluating a single project.

- Choosing the best project out of all possible alternatives.

Choosing a project out of all possible alternatives might be a non-trivial task, which depends on many circumstances. For example, there are individual risks thresholds that can be taken for different investors-larger companies can take larger risks if they are part of a bigger expected profit.

If the investor chooses between different projects using some trivial technique, for example, by comparing the expected profit values of different alternatives, then the choice can be easily automated as well; i.e., the choice between projects becomes a part of the investor's strategy. Thus, in this work 
we consider the most general case when different projects are evaluated and are followed by the choice between alternatives.

If the there is a need to apply some non-trivial (risk evaluation) technique for comparison of different projects, the approach provided is suitable to process every single project separately and extract the profit distribution-the information that can be applied for further analysis.

As it was mentioned already, roofing project evaluation involves the estimation of the subjective value of the construction object. Thus, the modelling of such a process must include some kind of the evaluation method, such as AHP. The existing solutions [25] for modelling of similar processes do not support such evaluation. Moreover, some process costs occur as additional costs with some probabilities; however, the occurrences of these costs do not change the structure of the tree. So including these costs into a decision tree would require duplicating some of branches of a tree. That should not be done by the user, since it can be done automatically.

\subsection{The Methods of the Research}

As it was mentioned before, the modelled process is Markov decision process, so a decision tree is a natural representation of it. However, differently from a typical Markov process, the current model lacks of information which must be derived (preprocessed); thus, we developed solutions in the most flexible and elegant form to process tree data structure-recursive algorithms. It is important to note that preprocessing does not introduce any additional computational errors. Thus, the final result is the exact solution due to the Bellman [26] principle which can be read as the optimal solution is the best out of optimal subsolutions, also known as dynamic programming.

The AHP method is suitable for application to the current problem due to a small number of evaluated parameters; it will be shown later. Also, the number of alternatives is small. It is equal to two. We will show that in conjunction with a decision tree, we can isolate the multi-criteria part of the problem to a single project evaluation. Two alternatives will be considered: to sell a project or not. Moreover, instead of direct usage of AHP method we will solve the inverse problem: the value of the price attribute will be chosen so that it will fit the threshold after which the decision change. i.e., the AHP method is directly used for the price evaluation instead of a typical usage to perform a decision. It will affect the decision via decision tree. Thus, we need to fit a single parameter for a monotonic function (for it to be equal to 0.5). We derived an explicit formula for that.

It should be emphasised that in AHP method the criteria hierarchy and weight value allocations are important. When more criteria are taken into consideration, the interrelations between criteria can be altered, and alternative hierarchies may influence the weights allocation [27]. The simplicity and the relative ease of use of the AHP method do not mean that it provides poor results [28]. Moreover, AHP method is widely used and is well-studied, making the results robust and interesting for a wide range of researchers. This widespread use is due to its ease of applicability and the structure of AHP which follows the intuitive way in which managers solve problems [29].

This research is dedicated to covering the already mentioned drawbacks of the existing solutions and show how apply the proposed methodology to roofing projects. This work makes the following contributions:

1. We analysed the participants and other specificities of a roofing project and showed how to describe such a process as a decision tree describing a Markov decision process.

2. We propose a modelling approach to evaluate the roofing project. The model was based on another work in [25], where the modelling did not support the specificity of the roofing project.

3. We propose to deal with the subjective evaluation of the projects' values using the AHP method; the details of its application for such projects are provided.

This paper is organised as follows. In Section 2 we present an example of roofing project's execution process and provide the details on algorithmic formalisation to perform the modelling of such process. The application of the model and the solution of the case study problem are provided in 
Section 3. At the end of the paper, we discuss the practical value and the conclusions of the research (Sections 4 and 5).

\section{The Creation of Mathematical Model}

\subsection{The Description of the Studied Case and Construction of the Decision Tree}

For modelling, the case of the situation where an investor can make decisions to carry out a roof installation project or not and to choose type of the project to select, depending on the risk assessment and the behaviour of participants, was investigated. Each situation, presented in decision tree, was related to the losses or incomes, and to the time used to resolve the situation, taking into account the risk as probability. Also the decisions about consultants and construction supervisor, building design company, project, construction company, suppliers and construction business partners selection were investigated. The decisions to sell the implemented project or not, in the model, were based on the market price of similar objects and the opinion of the project owner on how much the projects' results were worth for him in monetary units.

The model was provided with option that the project owner would be able to hire consultants which would receive a constant hourly wage, so the cost of consulting would depend on the duration of the project, were the consultants to be hired. It is also anticipated that the risk of project activities can be reduced by consulting.

The project owner has the opportunity to choose a building design company from two possibles. It is also foreseen that each building design company will prepare four roof installation projects, two expensive, and two of average prices, so in the model, eight projects were presented. Four of them were medium-priced roof projects: when an inexpensive roof with a simple loft was installed. The other four projects were expensive roof projects with a fully equipped loft and comfortable living space. It was taken into account that there can be losses related to the situations when additional investment is needed to correct a project, and alignment with the interested community and state organisations is necessary.

Another step was the choice of construction company. It was anticipated that for a single project it would be possible to select one from two construction companies.

Each building company was associated with the choice of two possible options of suppliers and construction business partners' organisations. Evaluation of losses due to additional investment if construction and supply organisation fails was included into the model.

The main decisions that must performed at the different project implementation stages are provided on the left part of the Figure 2. On the right part of the Figure 2 are what losses must be evaluated during the associated decisions.

The graph for the considered example is provided in Figure 3. Different types of nodes were used:

1. Decision nodes which are represented by rectangle shapes:

- Of blue colour-the decision on whether the project owner should sell the product or not;

- Of white colour with a yellow frame-the rest of decisions that should be made during the project.

2. End nodes that are represented by red rectangles.

3. Probability nodes represented by green ovals.

We also provide the zoomed-in fragment of the whole graph in Figure 4.

The detailed information about the data is provided in Appendix A and will be commented in more detail in the next section. 


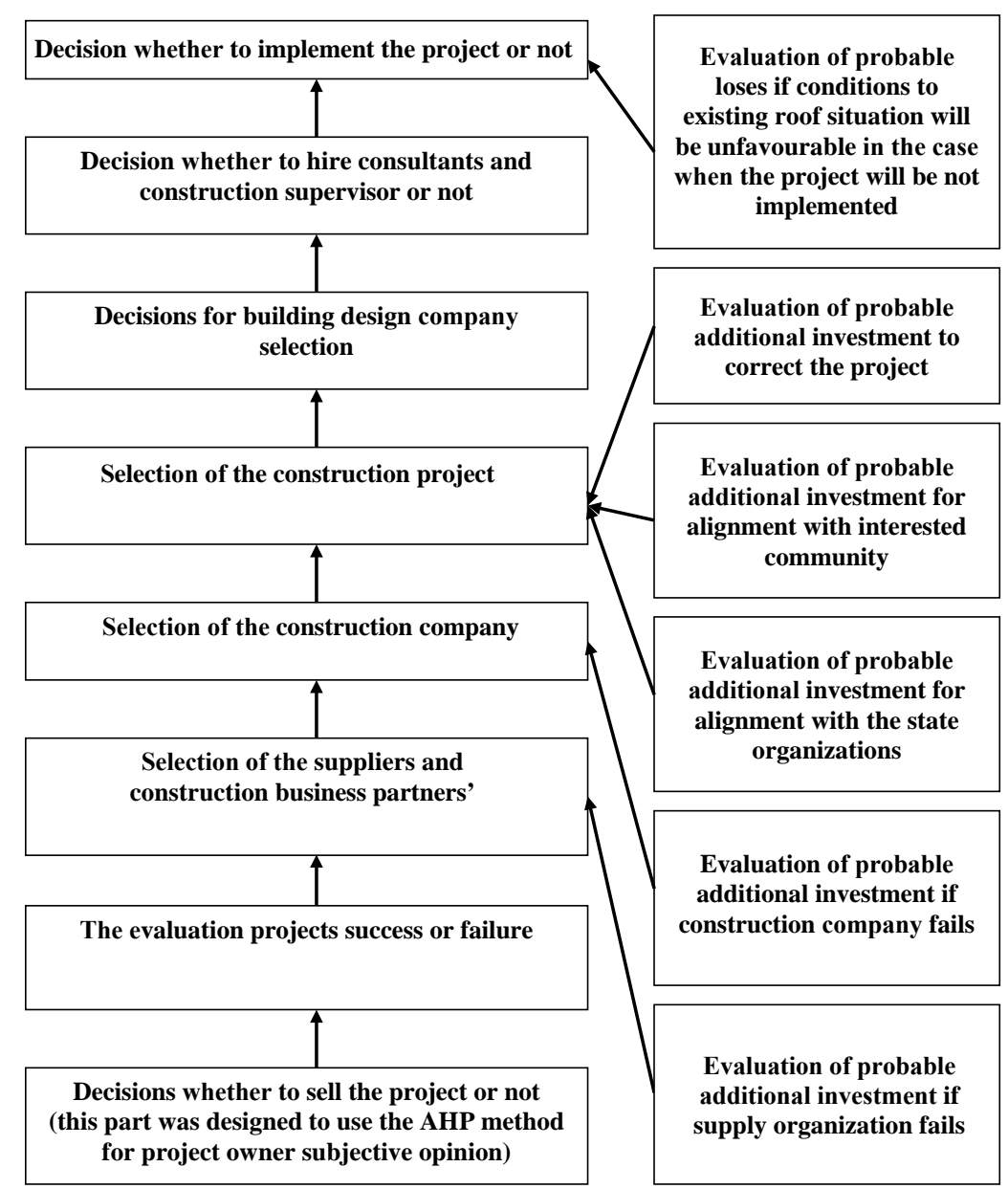

Figure 2. The main decisions at different stages of project's execution.

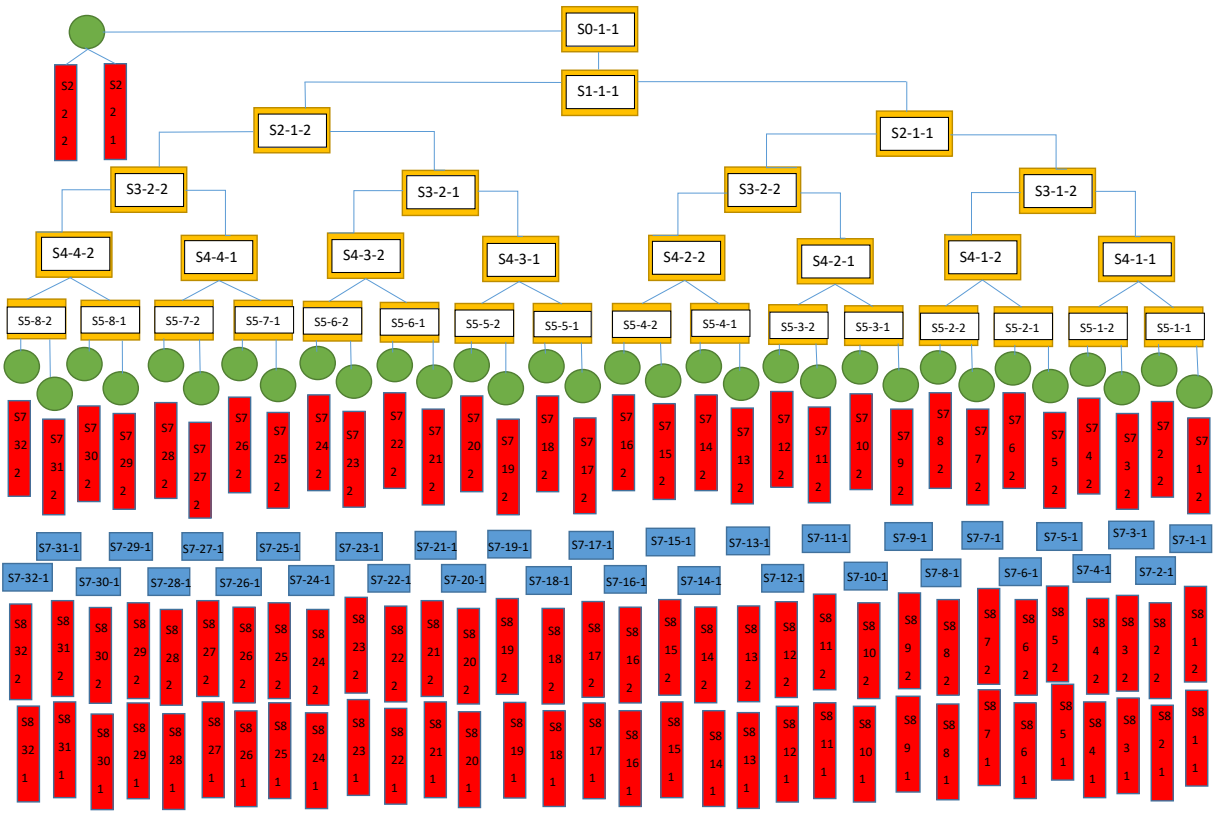

Figure 3. The graph for the example considered. 


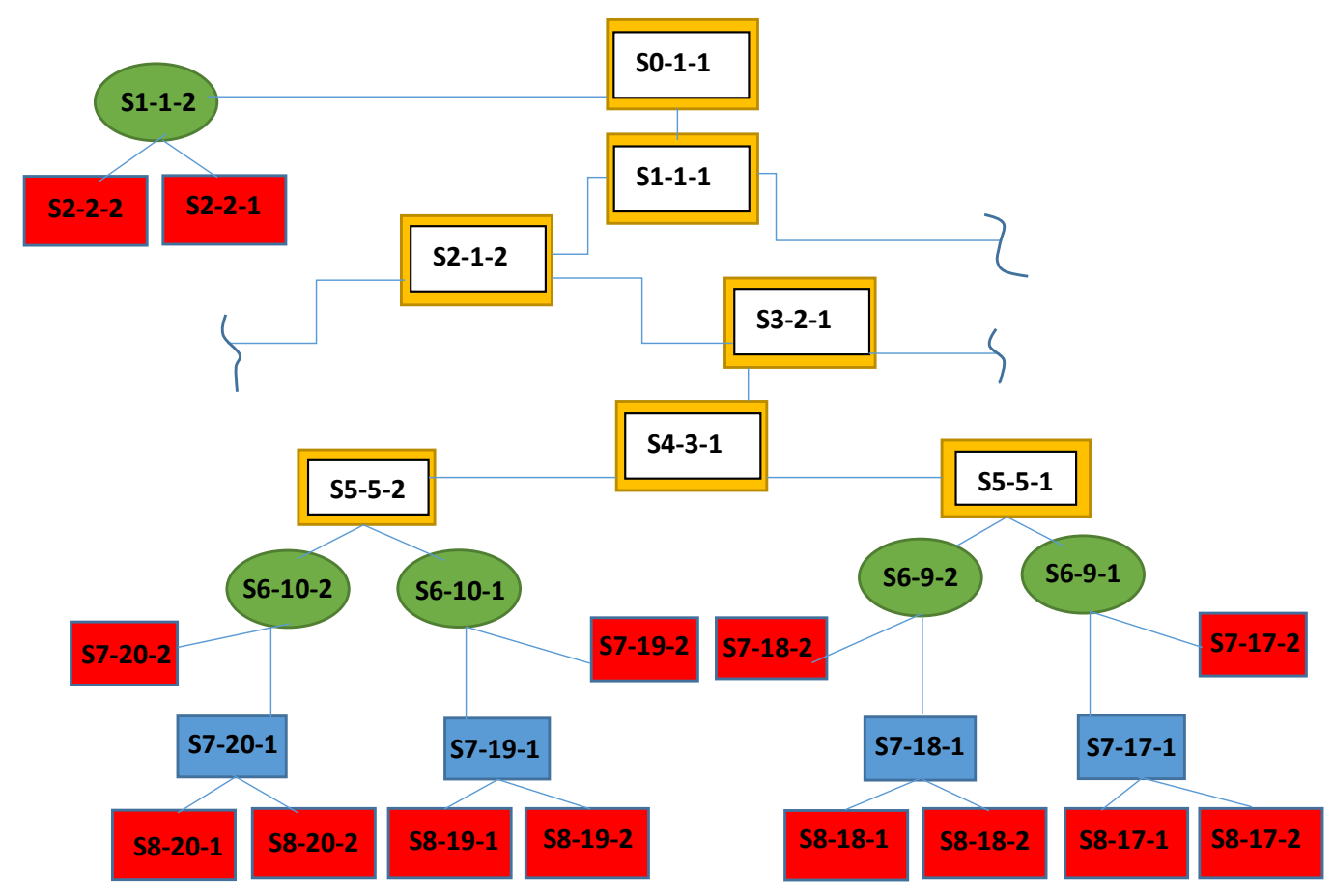

Figure 4. The zoomed-in fragment of the graph.

\subsection{The Mathematical Model}

The decision tree nodes represent the states which the project may be at. The transition between states will be referred to as an event. Which data will be stored at the node corresponds to the state the event transits to. Each task level consists of profit/loss values, which depend on the monetary value obtained at the previous state and probability of events or selection, optimising value (profit) for the customer. Since the decision tree has been divided into separate levels, the profit/loss is equal to the previous level's value (profit)/loss after evaluation of probability or decision made.

The objective is to maximise profit for the roof installation project owner, where a solution of decision strategy is defined by $X_{i j k}=0$ or 1 (integer input variables), $i=1,2,3 ; \ldots \mathrm{g}$ (the number of the decision tree level); $j=1,2,3, \ldots \mathrm{m}$ (the number of the branch group in the decision tree level); $k=1,2,3, \ldots \mathrm{n}$ (the number of the branch in the decision tree branch group); $X_{i j k} \geq 0 ; \sum_{k=1}^{n} X_{i j k}=1$; if $X_{i j k}=1-$ decision to take the action ijk; if $X_{i j k}=0$-decision do not to take the action ijk; if $P_{i j k}$ - probability of events, $P_{i j k} \geq 0 ; \sum_{k=1}^{n} P_{i j k}=1 ; S_{(i-1) j k}$ value (profit)/losses received after evaluation; for each decision tree branch group if decision must to be done:

$$
S_{(i-1) j k}=\sum_{k=1}^{n} S_{i j k} X_{i j k}
$$

or if there are probabilities of events:

$$
S_{(i-1) j k}=\sum_{k=1}^{n} S_{i j k} P_{i j k} .
$$

Also, each node in the tree has a duration parameter $t_{i j k}$ (measured in days). And if in decision tree position was the probability of events $P_{i j k}$, the expected time was also counted. The calculations provided total time for each branch of the tree, and the time planed for consultants and construction supervisor activity, if they were hired.

The basic element of our data structure (a tree) is a node with connections to parent and children nodes (Figure 5). 


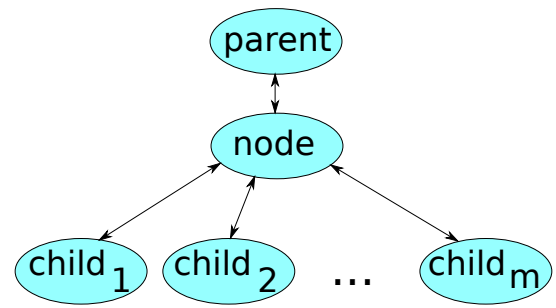

Figure 5. The relationships between a node and its parent and children nodes.

A more detailed description is presented in Algorithm 1, where the symbol "//" denotes comments that describe the corresponding fields.

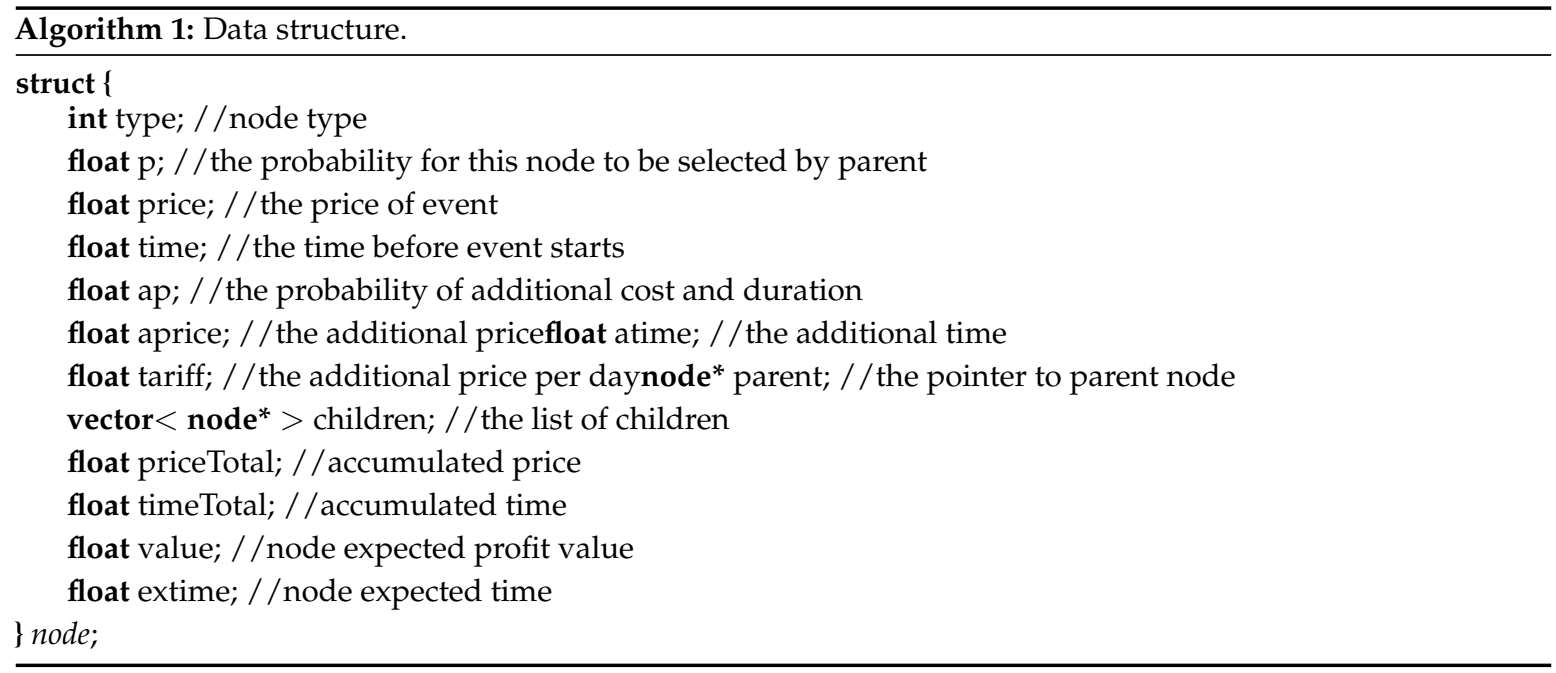

There are 12 fields in the provided structure in total. First eight are known from the data directly, some notes on these fields:

1. Field type describes the type of a node which can be either equal to 1, which means the investor decision node, or equal to 0 , which means all other nodes.

2. Field tariff denotes the cost which will be paid for every day of the project that after the node with this field is selected; i.e., the corresponding event activates the tariff mode, in our case primarily due to paying to consultations. Note, that the negative values of this field may stop the tariff mode period; however, for our particular case it will be not needed. I.e., it will be active until the project ends.

3. The pointers to the parent and the children nodes are defined by the graph edges.

As for the last four fields-they are computed by algorithms provided in this paper.

Note, that in all functions presented it is assumed that the arguments are passed by reference; i.e., the changes of arguments are seen outside of these functions. We propose the algorithm that consists of these steps:

1. Apply the AHP method to evaluate the values on leafs-we use field price with negative values for that.

2. Calculate total times (field timeTotal) and costs (field priceTotal) up to the moment when events are finished-this is implemented in the function CalcPars in Algorithm 2.

3. Evaluate end-node scenarios (calculate field value) and select optimal strategy-function CalcValues in Algorithm 3.

4. Create profit (field value) distribution by calculating different scenario probabilities. A simple implementation is provided in Algorithm 4. 

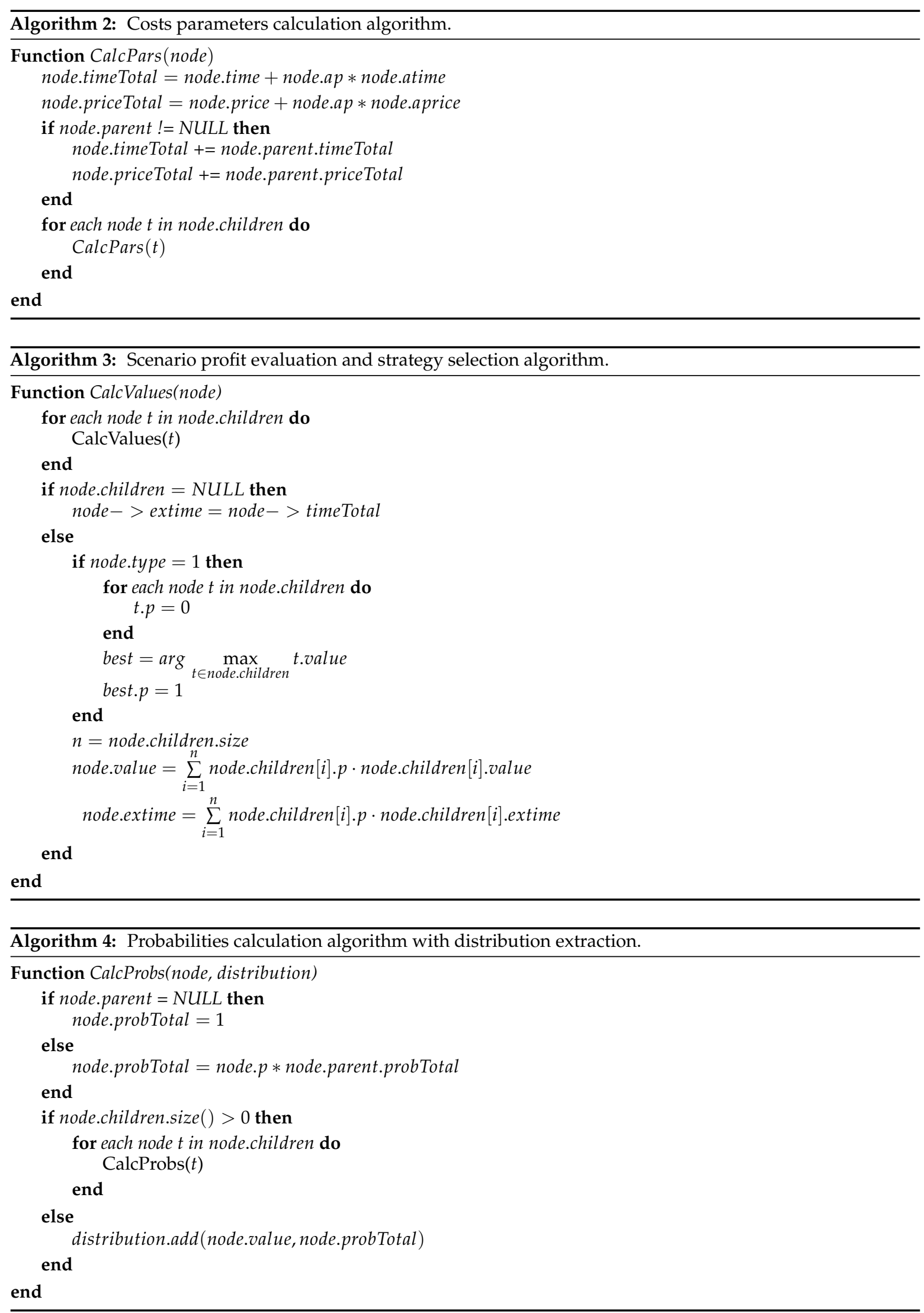

The algorithms were based on the results presented in [25]. We additionally included the support of additional costs with probabilities. There are two main techniques that were applied: 
1. Pre-order tree-traversal, when the calculations must be performed from top to the down of the tree; i.e., when each node must inherit the calculations part from the parent node.

2. Post-order tree-traversal, when the calculations must be performed from down to top; i.e., each node must collect the results from it's children and aggregate the result for itself-it is the implementation of a dynamic programming method.

Because the decision tree was limited to a monetary criterion, it was decided to search for additional approaches to take in consideration project owner's opinion, based on multi-criteria decision-making. In this field a lot of methods are created and used. For example, [30] proposed to use discrete stochastic multi-criteria decision-making method, based on distance from average solution, to handle many real-life decision-making problems.

We applied the AHP method to evaluate the roof installation projects taking into account the suitability for the chosen problem solution and the benefits visible from the works, where: subjective weightings were analysed by using the AHP computer software programme the Expert Choice 11 [31]; the AHP method was adopted in order to rank assessment themes and identify the priorities of the study's participating stakeholders [32]; a hierarchical structure for pavement alternatives was constructed and individual pairwise comparison was done by the experts [33].

It was found that the decision tree requires additional data about the value of the project, as it is subjectively perceived by the owner of the roof installation project. This data can be obtained by using the AHP method developed by T.L. Saaty [34].

The steps to use the AHP method to evaluate the price of the object:

1. Weighting of the criteria for AHP. For this step we need to form the matrix for pair-wise $\mathrm{C}_{l m}$ elements:

$$
\left[\begin{array}{cccc}
C_{11} & C_{12} & \ldots & C_{1 z} \\
C_{21} & C_{22} & \ldots & C_{2 z} \\
\ldots & \ldots & \ldots & \ldots \\
C_{z 1} & C_{z 2} & \ldots & C_{z z}
\end{array}\right]
$$

each entry in the matrix is positive $\left(C_{l m}>0\right)$ and reciprocal $\left(C_{l m}=1 / C_{l m}, \forall, m=1,2, \ldots z\right)$.

Then it is necessary to divide each element in the matrix by its column total:

$$
Y_{l m}=\frac{C_{l m}}{\sum_{l=1}^{z} C_{l m}} ;
$$

where $z$ is the number of criteria.

Then, it is possible to generate normalised, pair-wise matrix:

$$
\left[\begin{array}{cccc}
Y_{11} & Y_{12} & \ldots & Y_{1 z} \\
Y_{21} & Y_{22} & \ldots & Y_{2 z} \\
\ldots & \ldots & \ldots & \ldots \\
Y_{z 1} & Y_{z 2} & \ldots & Y_{z z}
\end{array}\right]
$$

If to divide the sum of normalised row of matrix by the number of criteria:

$$
W_{l}=\frac{\sum_{m=1}^{z} Y_{l m}}{z} ;
$$


we will have weighted matrix:

$$
\left[\begin{array}{c}
W_{1} \\
W_{2} \\
\ldots \\
W_{z}
\end{array}\right]
$$

the values of which represent different criteria weights.

To estimate the correctness of estimation (whether the evaluations for importance between different criteria are consistent), a consistency vector is calculated by dividing the weighted sum vector by criterion weight:

$$
\begin{gathered}
C v_{1}=\frac{1}{W_{1}}\left[C_{11} W_{1}+C_{12} W_{2}+\ldots+C_{1 z} W_{z}\right] ; \\
C v_{2}=\frac{1}{W_{2}}\left[C_{21} W_{1}+C_{22} W_{2}+\ldots+C_{2 z} W_{z}\right] ; \\
\ldots \\
C v_{z}=\frac{1}{W_{z}}\left[C_{z 1} W_{1}+C_{z 2} W_{2}+\ldots+C_{z z} W_{z}\right] .
\end{gathered}
$$

Eigen value $\lambda_{\max }$ is calculating by averaging the value of the consistency vector:

$$
\lambda_{\max }=\frac{1}{z} \sum_{l=1}^{z} C v_{l}
$$

a consistency index $(\mathrm{CI})$ :

$$
C I=\frac{\lambda_{\max }-z}{z-1}
$$

where $\lambda_{\max }$ is the maximal eigen value.

Consistency ratio:

$$
C R=\frac{C I}{R I}
$$

where RI is the random index.

In practice, a CR of 0.1 or below is considered acceptable. Any higher value at any level indicates that the judgements warrant re-examination.

2. Evaluation of the criteria for the projects A-H. An overall assessment of alternatives (to sell the object or not) for each of the project was planned to carry out without criteria of compliance with economic logic weighed by scores, because this criterion would be found for the situation where both alternatives are equal.

3. Finding the scores of economic logic for selling and reserving, for the roof owner, results in the same value (solution values are equal to 0.5 weighed and normalised points, because in this case we have only two alternatives). Here we assume a solution to be the value of the choice for the first alternative. To derive a formula we can exploit the fact that there are only two alternatives and write the solution in the simplified form

$$
F=\sum_{m=1}^{z} \frac{W_{m} V_{m}}{V_{m}+1}
$$

here, $V_{m}$ is the $m$-th criteria evaluation before the normalisation. Next, we express the score value of the first criteria 


$$
V_{1}=\frac{a}{1-a}, a=\left(F-\sum_{m=2}^{z} \frac{W_{m} V_{m}}{V_{m}+1}\right) / W_{1} .
$$

Substituting the needed value $F=0.5$ gives the desired result-the subjective price evaluation measured in score. In general the achieved result is not integer; therefore, we convert it into the price monetary value using linear interpolation of the values in table 2 . Note that the aforementioned table points are presented in a typical-for-AHP way-integers from -9 to 9 , excluding 0 , so before interpolation. we must perform additional mapping and use the value

$$
\bar{V}\left(V_{1}\right)= \begin{cases}-1 / V_{1}, & \text { when } V_{1}<1 \\ V_{1}, & \text { otherwise }\end{cases}
$$

\section{The Application of The Model}

Compliance with the psychological and social needs, economics logic, strategic objectives and best location variant criteria were chosen. It was done after a practical case study of construction projects and analysis of literature sources, in which the number of bedrooms, bathrooms, outdoor spa, swimming pool, garden, parking spaces, state of repair, architecture style, socioeconomic profile of neighbourhood, energy efficiency, distance [35], situation in the labour market, labour supply cost, amenities and neighbourhood quality [36], appropriative control of the green building project development [37], distance from the city centre and quality of the site [38], structural attributes, accessibility, public and private service amenities [39], city structure and house location [40] and strategy to rent [41], were factors for house pricing and housing strategy development. The goal of the AHP method, its criteria and its alternatives are presented in the Figure 6. Here are some comments about the criteria:

- The content of the criterion of compliance with the psychological and social needs is related to the situation of neighbourhood, habitual place, status, way of life, appearance, romanticism and history.

- Compliance with the economic logic criterion is related to the price of the object. It may also be related to energy consumption, maintenance, resale value and other costs-but for simplicity we did not include those.

- Compliance with the strategic objectives criterion is related to the owner's plans-whether the object will be rented, sold or used for living.

- Compliance with best location variant criterion is related to the quality of the site, accessibility and public and private service amenities.

In order to determine the weights of the criteria, the project owner had to assess which criterion were more important, and how important, with a score from 1 to 9 granting the alternative to sell the project and from -9 to -1 does not allow sale. The weights obtained after the calculations are given in the Table 1.

Then the project owner had to determine the scale for valuation of eight projects from $\mathrm{A}$ to $\mathrm{H}$, where points are related to the monetary value for him if not to sell the projects. The monetary value dependence on score is presented in linear form in Table 2.

Evaluation of the criteria was done by the project owner (decision to sell the object or not), and is presented in Table 3. Positions of compliance with economics logic were not evaluated by the project owner, because this number would be found by using the algorithm, whereby, knowing the non-linear dependency between the scores of the economic logic parameter (the score from 1 to 9 for alternative to sell the project and from -9 to -1 to not sell) and the evaluation of each project's alternatives without a compliance with economics logic parameter (on 0 to 1 scale), we can determine a economic logic parameter where both alternatives are the same; i.e., 0.5 weighed scores. This is clearly a subjective assessment. Knowing the scores, we can set the compliance with economic logic parameter from the 
scale system presented in Table 2. This is clearly a subjective assessment of the limit project value for owner if not to sell the roof for each project is presented in Table 4.

For comparison, the sale price for each project roof, based on analogues, is presented in Table 4. This data was incorporated into the decision tree branches.

The Algorithm 3 was applied to the tree, it was found that the best option for the consumer in economic terms would be to implement the project and sell the roof. The most effective way is from position $S_{8-12-1}$ to $S_{0-1-1}$, with a value of 5891.58 Euros. This is an average price project variant $C$, with a market sale price of 28,468 Euros. The cost of the project implementation would be of 22,576.4 Euros. The risk and additional costs were reduced by the choice of consultants and construction supervisor, although for them it was necessary to spend a considerable amount of money. The other organisations participating in the project chose taking into account the minimum cost for project $C$ implementation. The duration of the project was found-171.003 days, which takes into account the probabilities of probable time losses. The tariff for consulting was 6.25 Euros per day.

Expensive projects were not selected because the best option was D, with the value of 3345 Euros, which is less than for the project $C$. The results of modelling for these expensive projects showed that the owner does not sell the roof, but its installation costs are higher and the projects last longer.

Based on the results, if one does not to take the project activity, expected loses can be of 1000 Euros.

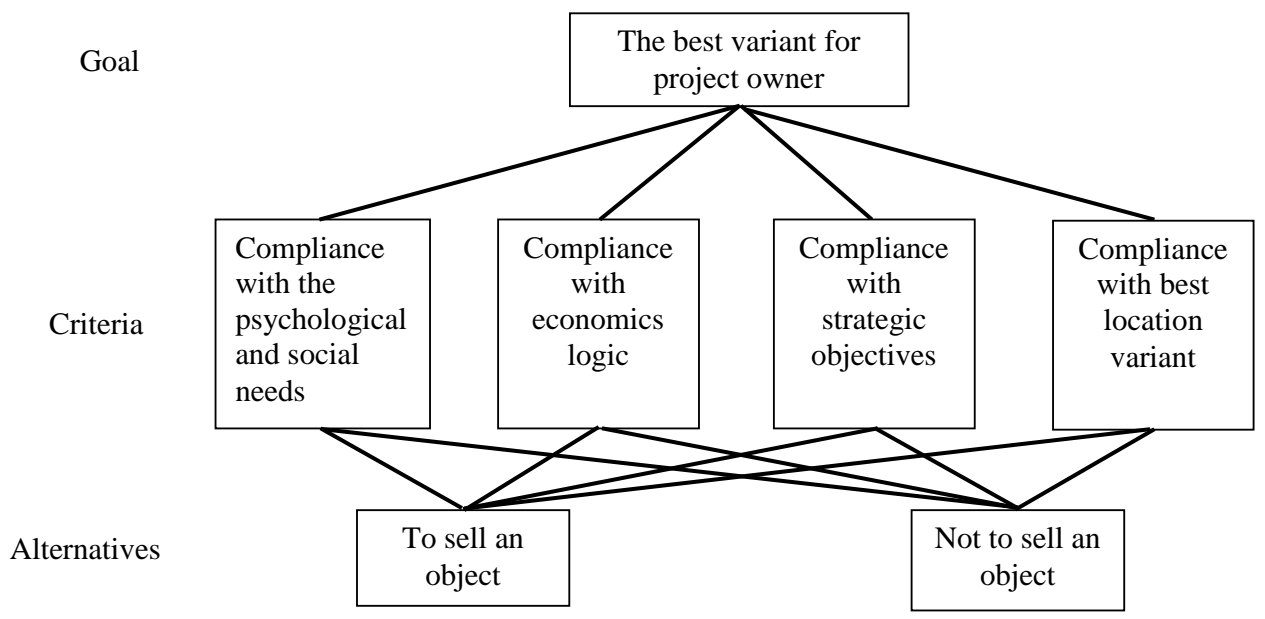

Figure 6. AHP hierarchy for roofing project.

Table 1. Weights for the criteria.

\begin{tabular}{ccccc}
\hline Criteria & $\begin{array}{c}\text { Compliance with the } \\
\text { Psychological and Social Needs }\end{array}$ & $\begin{array}{c}\text { Compliance with Economics Logic } \\
\text { Economics Logic }\end{array}$ & $\begin{array}{c}\text { Compliance with } \\
\text { Strategic Objectives }\end{array}$ & $\begin{array}{c}\text { Compliance with } \\
\text { Best Location Variant }\end{array}$ \\
\hline Weights & 0.1376 & 0.3935 & 0.3935 & 0.0754 \\
\hline
\end{tabular}

Table 2. The scale to connect points system and monetary value of the project.

\begin{tabular}{|c|c|c|c|c|c|c|c|c|}
\hline \multirow[t]{2}{*}{ Points System } & \multicolumn{8}{|c|}{ Projects A-H Value Scale for the Owner in Euros } \\
\hline & A & B & $\mathrm{C}$ & $\mathbf{D}$ & $\mathbf{E}$ & $\mathbf{F}$ & G & $\mathbf{H}$ \\
\hline 9 & 16,694 & 34,800 & 17,694 & 36,000 & 15,194 & 32,300 & 16,194 & 33,500 \\
\hline 8 & 17,694 & 37,300 & 18,694 & 38,500 & 16,194 & 34,800 & 17,194 & 36,000 \\
\hline 7 & 18,694 & 39,800 & 19,694 & 41,000 & 17,194 & 37,300 & 18,194 & 38,500 \\
\hline 6 & 19,694 & 42,300 & 20,694 & 43,500 & 18,194 & 39,800 & 19,194 & 41,000 \\
\hline 5 & 20,694 & 44,800 & 21,694 & 46,000 & 19,194 & 42,300 & 20,194 & 43,500 \\
\hline 4 & 21,694 & 47,300 & 22,694 & 48,500 & 20,194 & 44,800 & 21,194 & 46,000 \\
\hline 3 & 22,694 & 49,800 & 23,694 & 51,000 & 21,194 & 47,300 & 22,194 & 48,500 \\
\hline
\end{tabular}


Table 2. Cont.

\begin{tabular}{|c|c|c|c|c|c|c|c|c|}
\hline \multirow[t]{2}{*}{ Points System } & \multicolumn{8}{|c|}{ Projects A-H Value Scale for the Owner in Euros } \\
\hline & A & B & $\mathrm{C}$ & $\mathbf{D}$ & $\mathbf{E}$ & F & G & $\mathbf{H}$ \\
\hline 2 & 23,694 & 52,300 & 24,694 & 53,500 & 22,194 & 49,800 & 23,194 & 51,000 \\
\hline 1 & 24,694 & 54,800 & 25,694 & 56,000 & 23,194 & 52,300 & 24,194 & 53,500 \\
\hline-1 & 24,694 & 54,800 & 25,694 & 56,000 & 23,194 & 52,300 & 24,194 & 53,500 \\
\hline-2 & 25,694 & 57,300 & 26,694 & 58,500 & 24,194 & 54,800 & 25,194 & 56,000 \\
\hline-3 & 26,694 & 59,800 & 27,694 & 61,000 & 25,194 & 57,300 & 26,194 & 58,500 \\
\hline-4 & 27,694 & 62,300 & 28,694 & 63,500 & 26,194 & 59,800 & 27,194 & 61,000 \\
\hline-5 & 28,694 & 64,800 & 29,694 & 66,000 & 27,194 & 62,300 & 28,194 & 63,500 \\
\hline-6 & 29,694 & 67,300 & 30,694 & 68,500 & 28,194 & 64,800 & 29,194 & 66,000 \\
\hline-7 & 30,694 & 69,800 & 31,694 & 71,000 & 29,194 & 67,300 & 30,194 & 68,500 \\
\hline-8 & 31,694 & 72,300 & 32,694 & 73,500 & 30,194 & 69,800 & 31,194 & 71,000 \\
\hline-9 & 32,694 & 74,800 & 33,694 & 76,000 & 31,194 & 72,300 & 32,194 & 73,500 \\
\hline
\end{tabular}

Table 3. Evaluation of the criteria by the customer (decision to sell the object or not).

\begin{tabular}{|c|c|c|c|c|c|c|c|c|}
\hline \multirow[t]{2}{*}{ Criteria } & \multicolumn{8}{|c|}{ Projects A-H Alternatives Evaluation in Points } \\
\hline & A & B & C & $\mathbf{D}$ & $\mathbf{E}$ & $\mathbf{F}$ & G & $\mathbf{H}$ \\
\hline Compliance with the psychological and social needs & -3 & -5 & -3 & -5 & -3 & -5 & -3 & -5 \\
\hline Compliance with strategic objectives & -2 & -2 & -1 & -1 & -3 & -3 & -2 & -2 \\
\hline Compliance with best location variant & 2 & 2 & 2 & 2 & 2 & 2 & 2 & 2 \\
\hline $\begin{array}{l}\text { Compliance with economics logic, points from AHP, } \\
\text { when both alternatives are equal }\end{array}$ & 2.60 & 3.02 & 1.25 & 1.41 & 4.14 & 5.05 & 2.60 & 3.02 \\
\hline
\end{tabular}

Table 4. Final alternatives to sell or not data for entering into decision tree (to select best variant).

\begin{tabular}{lcccccccc}
\hline Criteria & Projects in Euros & & & & \\
\hline & A & B & C & D & E & F & G & H \\
\hline Limit value if we reserve for ourselves from AHP & 23,095 & 49,748 & 25,444 & 54,981 & 20,053 & 42,183 & 22,595 & 48,448 \\
\hline
\end{tabular}

\section{Discussion}

The authors of the article proposed the methodology, which lets one model the behaviour of roof installation project participants, and they applied it to the example case. Application of the results is useful:

1. If it is necessary to select the economically best project from a set of possible alternatives.

2. If it is necessary to take into account the stages involved in the project and the needs of the main stakeholders, and review different scenarios.

3. If individual parameters (criteria) need to be assessed and transferred to monetary value.

We showed how to isolate the multi-criteria part of the problem and model it separately from the decision tree. Instead of including it into a tree processing logic, we derived the threshold value of the price which is on the edge between the solution to sell the roof or not, and we used this value as the subjective price evaluation which was added to the profit value-it affected the decision via single criteria Markov process modelling.

There were some assumptions made that might be revised; for example, in Algorithm 3 the formula best $=\arg \max _{t \in \text { node.children }}$ t.value was used, which means a branch of a tree is evaluated by the expected profit value alone; however, for an investor the most important thing might be the profit per 
time unit. Still, the proposed approach is flexible enough and easy to enough modify to support such an evaluation as well; instead of t.value the value t.value/t.extime can be used. Some more advanced techniques could be used for risk analysis, etc. However, it might break the conditions which are necessary for the Bellman [26] principle leading to the loss of the optimality. But even without those conditions it might lead to a decent heuristic with a reasonably good results. That might be the subject of the future research.

The proper (advanced) risk evaluation techniques are out of scope of this research. The project selection from several alternatives might be done outside of the proposed methodology-it lets us evaluate different projects separately, which can be followed by processing with some advanced risk evaluation tools.

Regarding AHP sensitivity analysis, we donot apply the AHP directly. We solve the inverse problem to extract the threshold value for the object price. Next, we apply this price as a price evaluation in Markov process modelling; this is where the choice of the project is performed. This means, that even if the choice of the project is sensitive to some criteria evaluation, then the actual difference of profit values will be small. A sensitive choice would mean small difference in profit values. Therefore, it is not reasonable to apply the sensitivity analysis in the scope of the current research. Such analysis could be useful to determining the importance of different criteria; however, that is out of scope of the current research.

\section{Conclusions}

1. A combination of decision tree and AHP techniques covered the needs of this research; i.e., the decision tree directly describes the real process, and AHP lets one estimate some of the states of this process, which are not known initially. More specifically—it lets one perform a multi-criteria evaluation of the subjective prices of the projects (for each of them separately) according to the project owner's opinion.

2. The proposed approach lets one perform modelling with a large number of possible alternatives automatically. Therefore, the number of alternatives and the size of the tree itself depends on the user and is limited by a human factor alone. A limited number of possible alternatives can be reviewed, as the process of creating alternatives is rather labour-intensive and may take a lot of time.

3. The probabilistic parameters of the model are related to the market situation; however, the project decisions evaluated at the current moment and the situation during the project implementation can change. This risk can be controlled by extending the tree with possible scenario nodes; thus, it can be easily be performed by a user.

4. The estimation of the information that is necessary to fill the model by the data can be a non-trivial task. For example, in order to apply the proposed methodology, it is necessary to evaluate the costs of each project implementation. In addition, some project details may be unknown, and some data should be evaluated without exact information as well. However, the proposed methodology supports non-determinism, which partially solves the aforementioned problems. Technically, it means that instead of a single scenario, a few possible scenarios can be used with given probabilities.

5. Evaluation and implementation of the project is directly linked to the specific project owner; he can have personal reasons to consider why and how valuable the project is for him. The AHP method enables one to include this information into a model.

6. In this work, the computational part of the methodology is provided in the flexible form of general algorithm description through pseudo code. This lets one implement the technique easily, using general-purpose programming languages, such as Java, Python, $\mathrm{C}++$, etc. Thus, the results provided here can be easily integrated into other systems, such as business management, insurance and expert systems. 
Author Contributions: O.R.Š. and A.M. formulated the problem, and collected and analysed the data; A.B. created appropriate algorithms, implemented them in $\mathrm{C}++$ and wrote pseudocode. All authors contributed to performing experiments, analysis of results and writing the paper equally.

Funding: This research received no external funding.

Conflicts of Interest: The authors declare no conflict of interest.

\section{Appendix A}

Table A1. Description of the transition from one state to another in the decision tree, part 1.

\begin{tabular}{|c|c|}
\hline Marking of the Edges $S_{i-1 j k}-S_{i j k}$ & $\begin{array}{l}\text { Description of Behavioural Options and Probable } \\
\text { Events }\end{array}$ \\
\hline $\mathrm{S}_{0-1-1}-\mathrm{S}_{1-1-1}$ & Project owner decided to carry out the project \\
\hline $\mathrm{S}_{0-1-1}-\mathrm{S}_{1-1-2}$ & Project owner refuses the project \\
\hline $\mathrm{S}_{1-1-1}-\mathrm{S}_{2-1-1}$ & $\begin{array}{l}\text { Project owner decided to hire the consultants and } \\
\text { supervisor }\end{array}$ \\
\hline $\mathrm{S}_{1-1-1}-\mathrm{S}_{2-1-2}$ & $\begin{array}{l}\text { Project owner decided do not to hire the consultants } \\
\text { and supervisor }\end{array}$ \\
\hline$S_{1-1-2}-S_{2-2-1}$ & $\begin{array}{l}\text { The loses if conditions to existing roof situation are } \\
\text { unfavourable }\end{array}$ \\
\hline$S_{1-1-2}-S_{2-2-2}$ & $\begin{array}{l}\text { The loses if conditions to existing roof situation are } \\
\text { favourable }\end{array}$ \\
\hline $\mathrm{S}_{2-1-1}-\mathrm{S}_{3-1-1}$ & $\begin{array}{l}\text { Project owner decided to select the building design } \\
\text { company " } \mathrm{A} \text { " (with consulting) }\end{array}$ \\
\hline $\mathrm{S}_{2-1-1}-\mathrm{S}_{3-1-2}$ & $\begin{array}{l}\text { Project owner decided to select the building design } \\
\text { company "B" (with consulting) }\end{array}$ \\
\hline$S_{2-1-2}-S_{3-2-1}$ & $\begin{array}{l}\text { Project owner decided to select the building design } \\
\text { company " } \mathrm{A} \text { " (without consulting) }\end{array}$ \\
\hline$S_{2-1-2}-S_{3-2-2}$ & $\begin{array}{l}\text { Project owner decided to select the building design } \\
\text { company "B" (without consulting) }\end{array}$ \\
\hline $\begin{array}{lll}\mathrm{S}_{3-1-1}-\mathrm{S}_{4-1-1} ; & \mathrm{S}_{3-1-1}-\mathrm{S}_{4-1-2} ; & \mathrm{S}_{3-1-2}-\mathrm{S}_{4-2-1} \\
\mathrm{~S}_{3-1-2}-\mathrm{S}_{4-2-2} ; & \mathrm{S}_{3-2-1}-\mathrm{S}_{4-3-1} ; & \mathrm{S}_{3-2-1}-\mathrm{S}_{4-3-2} \\
\mathrm{~S}_{3-2-2}-\mathrm{S}_{4-4-1} ; \mathrm{S}_{3-2-2}-\mathrm{S}_{4-4-2} & \end{array}$ & $\begin{array}{l}\text { Project owner decided to select the medium price } \\
\text { project " } \mathrm{A} \text { " or expensive project " } \mathrm{B} \text { " for building } \\
\text { design company " } \mathrm{A} \text { " (with consulting); " } \mathrm{C} \text { " or " } \mathrm{D} \text { " } \\
\text { for " } \mathrm{B} \text { " (with consulting); " } \mathrm{E} \text { " or " } \mathrm{F} \text { " for " } \mathrm{A} \text { " (without } \\
\text { consulting); " } \mathrm{G} \text { " or " } \mathrm{H} \text { " for " } \mathrm{B} \text { " (without consulting) }\end{array}$ \\
\hline $\begin{array}{lll}\mathrm{S}_{4-1-1}-\mathrm{S}_{5-1-1} ; & \mathrm{S}_{4-1-1}-\mathrm{S}_{5-1-2} ; & \mathrm{S}_{4-1-2}-\mathrm{S}_{5-2-1} ; \\
\mathrm{S}_{4-1-2}-\mathrm{S}_{5-2-2} ; & \mathrm{S}_{4-2-1}-\mathrm{S}_{5-3-1} ; & \mathrm{S}_{4-2-1}-\mathrm{S}_{5-3-2} ; \\
\mathrm{S}_{4-2-2}-\mathrm{S}_{5-4-1} ; & \mathrm{S}_{4-2-2}-\mathrm{S}_{5-4-2} ; & \mathrm{S}_{4-3-1}-\mathrm{S}_{5-5-1} ; \\
\mathrm{S}_{4-3-1}-\mathrm{S}_{5-5-2} ; & \mathrm{S}_{4-3-2}-\mathrm{S}_{5-6-1} ; & \mathrm{S}_{4-3-2}-\mathrm{S}_{5-6-2} ; \\
\mathrm{S}_{4-4-1}-\mathrm{S}_{5-7-1} ; & \mathrm{S}_{4-4-1}-\mathrm{S}_{5-7-2} ; & \mathrm{S}_{4-4-2}-\mathrm{S}_{5-8-1} ; \\
\mathrm{S}_{4-4-2} \mathrm{~S}_{5-8-2} & & \\
\end{array}$ & 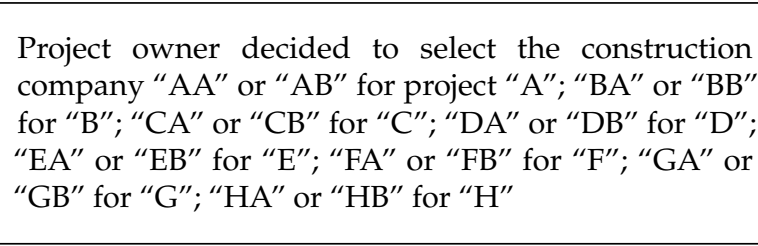 \\
\hline $\begin{array}{lll}\mathrm{S}_{5-1-1}-\mathrm{S}_{6-1-1} ; & \mathrm{S}_{5-1-1}-\mathrm{S}_{6-1-2} ; & \mathrm{S}_{5-1-2}-\mathrm{S}_{6-2-1} \\
\mathrm{~S}_{5-1-2}-\mathrm{S}_{6-2-2} ; & \mathrm{S}_{5-2-1}-\mathrm{S}_{6-3-1} ; & \mathrm{S}_{5-2-1}-\mathrm{S}_{6-3-2} ; \\
\mathrm{S}_{5-2-2}-\mathrm{S}_{6-4-1} ; & \mathrm{S}_{5-2-2}-\mathrm{S}_{6-4-2} ; & \mathrm{S}_{5-3-1}-\mathrm{S}_{6-5-1} ; \\
\mathrm{S}_{5-3-1}-\mathrm{S}_{6-5-2} ; & \mathrm{S}_{5-3-2}-\mathrm{S}_{6-6-1} ; & \mathrm{S}_{5-3-2}-\mathrm{S}_{6-6-2} ; \\
\mathrm{S}_{5-4-1}-\mathrm{S}_{6-7-1} ; & \mathrm{S}_{5-4-1}-\mathrm{S}_{6-7-2} ; & \mathrm{S}_{5-4-2}-\mathrm{S}_{6-8-1} \\
\mathrm{~S}_{5-4-2}-\mathrm{S}_{6-8-2} ; & \mathrm{S}_{5-5-1}-\mathrm{S}_{6-9-1} ; & \mathrm{S}_{5-5-1}-\mathrm{S}_{6-9-2} ; \\
\mathrm{S}_{5-5-2}-\mathrm{S}_{6-10-1} ; \mathrm{S}_{5-5-2}-\mathrm{S}_{6-10-2} ; \mathrm{S}_{5-6-1}-\mathrm{S}_{6-11-1} ; \\
\mathrm{S}_{5-6-1}-\mathrm{S}_{6-11-2} ; \mathrm{S}_{5-6-2}-\mathrm{S}_{6-12-1} ; \mathrm{S}_{5-6-2}-\mathrm{S}_{6-12-2} ; \\
\mathrm{S}_{5-7-1}-\mathrm{S}_{6-13-1} ; \mathrm{S}_{5-7-1}-\mathrm{S}_{6-13-2} ; \mathrm{S}_{5-7-2}-\mathrm{S}_{6-14-1} ; \\
\mathrm{S}_{5-7-2}-\mathrm{S}_{6-14-2} ; \mathrm{S}_{5-8-1}-\mathrm{S}_{6-15-1} ; \mathrm{S}_{5-8-1}-\mathrm{S}_{6-15-2} ; \\
\mathrm{S}_{5-8-2}-\mathrm{S}_{6-16-1} ; \mathrm{S}_{5-8-2}-\mathrm{S}_{6-16-2}\end{array}$ & 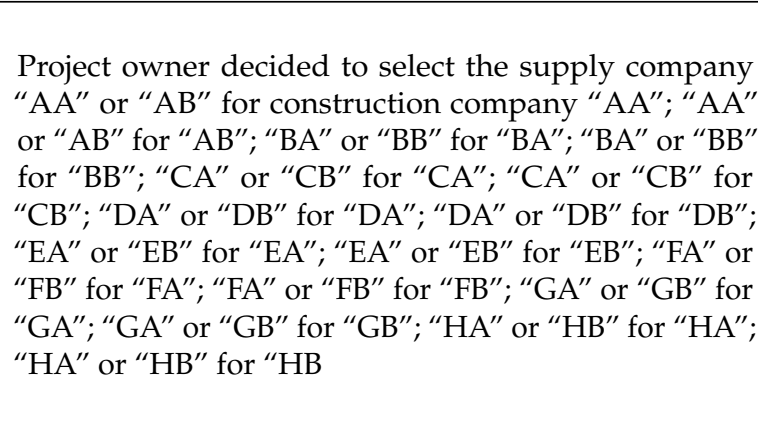 \\
\hline
\end{tabular}


Table A2. Description of the transition from one state to another in the decision tree, part 2.

\begin{tabular}{|c|c|}
\hline $\begin{array}{llll}\mathrm{S}_{6-1-1}-\mathrm{S}_{7-1-1} ; & \mathrm{S}_{6-1-2}-\mathrm{S}_{7-2-1} ; & \mathrm{S}_{6-2-1}-\mathrm{S}_{7-3-1} ; & \mathrm{S}_{6-2-2}-\mathrm{S}_{7-4-1} \\
\mathrm{~S}_{6-3-1}-\mathrm{S}_{7-5-1} ; & \mathrm{S}_{6-3-2}-\mathrm{S}_{7-6-1} ; & \mathrm{S}_{6-4-1}-\mathrm{S}_{7-7-1} ; & \mathrm{S}_{6-4-2}-\mathrm{S}_{7-8-1} \\
\mathrm{~S}_{6-5-1}-\mathrm{S}_{7-9-1} ; & \mathrm{S}_{6-5-2}-\mathrm{S}_{7-10-1} ; & \mathrm{S}_{6-6-1}-\mathrm{S}_{7-11-1} ; & \mathrm{S}_{6-6-2}-\mathrm{S}_{7-12-1} \\
\mathrm{~S}_{6-7-1}-\mathrm{S}_{7-13-1} ; & \mathrm{S}_{6-7-2}-\mathrm{S}_{7-14-1} ; & \mathrm{S}_{6-8-1}-\mathrm{S}_{7-15-1} ; & \mathrm{S}_{6-8-2}-\mathrm{S}_{7-16-1} ; \\
\mathrm{S}_{6-9-1}-\mathrm{S}_{7-17-1} ; & \mathrm{S}_{6-9-2}-\mathrm{S}_{7-18-1} ; & \mathrm{S}_{6-10-1}-\mathrm{S}_{7-19-1} ; & \mathrm{S}_{6-10-2}-\mathrm{S}_{7-20-1} \\
\mathrm{~S}_{6-11-1}-\mathrm{S}_{7-21-1} ; & \mathrm{S}_{6-11-2}-\mathrm{S}_{7-22-1} ; & \mathrm{S}_{6-12-1}-\mathrm{S}_{7-23-1} ; & \mathrm{S}_{6-12-2}-\mathrm{S}_{7-24-1} ; \\
\mathrm{S}_{6-13-1}-\mathrm{S}_{7-25-1} ; & \mathrm{S}_{6-13-2}-\mathrm{S}_{7-26-1} ; & \mathrm{S}_{6-14-1}-\mathrm{S}_{7-27-1} ; & \mathrm{S}_{6-14-2}-\mathrm{S}_{7-28-1} ; \\
\mathrm{S}_{6-15-1}-\mathrm{S}_{7-29-1} ; & \mathrm{S}_{6-15-2}-\mathrm{S}_{7-30-1} ; \mathrm{S}_{6-16-1}-\mathrm{S}_{7-31-1} ; \mathrm{S}_{6-16-2}-\mathrm{S}_{7-32-1}\end{array}$ & $\begin{array}{l}\text { Variant of project implemented } \\
\text { with success }\end{array}$ \\
\hline $\begin{array}{llll}\mathrm{S}_{6-1-1}-\mathrm{S}_{7-1-2} ; & \mathrm{S}_{6-1-2}-\mathrm{S}_{7-2-2} ; & \mathrm{S}_{6-2-1}-\mathrm{S}_{7-3-2} ; & \mathrm{S}_{6-2-2}-\mathrm{S}_{7-4-2} ; \\
\mathrm{S}_{6-3-1}-\mathrm{S}_{7-5-2} ; & \mathrm{S}_{6-3-2}-\mathrm{S}_{7-6-2} ; & \mathrm{S}_{6-4-1}-\mathrm{S}_{7-7-2} ; & \mathrm{S}_{6-4-2}-\mathrm{S}_{7-8-2} \\
\mathrm{~S}_{6-5-1}-\mathrm{S}_{7-9-2} ; & \mathrm{S}_{6-5-2}-\mathrm{S}_{7-10-2} ; & \mathrm{S}_{6-6-1}-\mathrm{S}_{7-11-2} ; & \mathrm{S}_{6-6-2}-\mathrm{S}_{7-12-2} ; \\
\mathrm{S}_{6-7-1}-\mathrm{S}_{7-13-2} ; & \mathrm{S}_{6-7-2}-\mathrm{S}_{7-14-2} ; & \mathrm{S}_{6-8-1}-\mathrm{S}_{7-15-2} ; & \mathrm{S}_{6-8-2}-\mathrm{S}_{7-16-2} ; \\
\mathrm{S}_{6-9-1}-\mathrm{S}_{7-17-2} ; & \mathrm{S}_{6-9-2}-\mathrm{S}_{7-18-2} ; & \mathrm{S}_{6-10-1}-\mathrm{S}_{7-19-2} ; & \mathrm{S}_{6-10-2}-\mathrm{S}_{7-20-2} ; \\
\mathrm{S}_{6-11-1}-\mathrm{S}_{7-21-2} ; \mathrm{S}_{6-11-2-\mathrm{S}_{7-22-2}} ; \mathrm{S}_{6-12-1}-\mathrm{S}_{7-23-2} ; & \mathrm{S}_{6-12-2}-\mathrm{S}_{7-24-2} ; \\
\mathrm{S}_{6-13-1}-\mathrm{S}_{7-25-2} ; \mathrm{S}_{6-13-2}-\mathrm{S}_{7-26-2} ; & \mathrm{S}_{6-14-1}-\mathrm{S}_{7-27-2} ; \mathrm{S}_{6-14-2}-\mathrm{S}_{7-28-2} ; \\
\mathrm{S}_{6-15-1}-\mathrm{S}_{7-29-2} ; \mathrm{S}_{6-15-2}-\mathrm{S}_{7-30-2} ; \mathrm{S}_{6-16-1}-\mathrm{S}_{7-31-2} ; & \mathrm{S}_{6-16-2}-\mathrm{S}_{7-32-2}\end{array}$ & $\begin{array}{l}\text { Variant of project implemented } \\
\text { with total fail }\end{array}$ \\
\hline 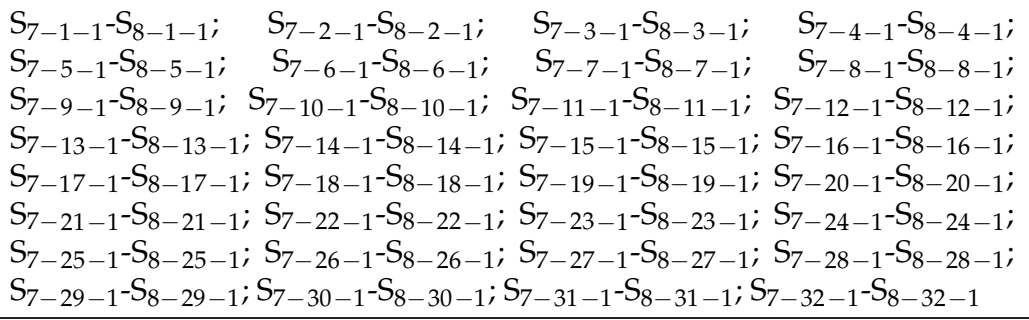 & $\begin{array}{l}\text { Project owner decided to sell } \\
\text { the object and gain the profit or } \\
\text { loses }\end{array}$ \\
\hline $\begin{array}{llll}\mathrm{S}_{7-1-1}-\mathrm{S}_{8-1-2} ; & \mathrm{S}_{7-2-1}-\mathrm{S}_{8-2-2} ; & \mathrm{S}_{7-3-1}-\mathrm{S}_{8-3-2} ; & \mathrm{S}_{7-4-1}-\mathrm{S}_{8-4-2} ; \\
\mathrm{S}_{7-5-1}-\mathrm{S}_{8-5-2} ; & \mathrm{S}_{7-6-1}-\mathrm{S}_{8-6-2} ; & \mathrm{S}_{7-7-1}-\mathrm{S}_{8-7-2} ; & \mathrm{S}_{7-8-1}-\mathrm{S}_{8-8-2} \\
\mathrm{~S}_{7-9-1}-\mathrm{S}_{8-9-2} ; \mathrm{S}_{7-10-1}-\mathrm{S}_{8-10-2} ; & \mathrm{S}_{7-11-1}-\mathrm{S}_{8-11-2} ; \mathrm{S}_{7-12-1}-\mathrm{S}_{8-12-2} ; \\
\mathrm{S}_{7-13-1}-\mathrm{S}_{8-13-2} ; \mathrm{S}_{7-14-1}-\mathrm{S}_{8-14-2} ; \mathrm{S}_{7-15-1}-\mathrm{S}_{8-15-2} ; \mathrm{S}_{7-16-1}-\mathrm{S}_{8-16-2} ; \\
\mathrm{S}_{7-17-1}-\mathrm{S}_{8-17-2} ; \mathrm{S}_{7-18-1}-\mathrm{S}_{8-18-2} ; \mathrm{S}_{7-19-1}-\mathrm{S}_{8-19-2} ; \mathrm{S}_{7-20-1}-\mathrm{S}_{8-20-2} ; \\
\mathrm{S}_{7-21-1}-\mathrm{S}_{8-21-2} ; \mathrm{S}_{7-22-1}-\mathrm{S}_{8-22-2} ; \mathrm{S}_{7-23-1}-\mathrm{S}_{8-23-2} ; \mathrm{S}_{7-24-1}-\mathrm{S}_{8-24-2} ; \\
\mathrm{S}_{7-25-1}-\mathrm{S}_{8-25-2} ; \mathrm{S}_{7-26-1}-\mathrm{S}_{8-26-2} ; \mathrm{S}_{7-27-1}-\mathrm{S}_{8-27-2} ; \mathrm{S}_{7-28-1}-\mathrm{S}_{8-28-2} ; \\
\mathrm{S}_{7-29-1}-\mathrm{S}_{8-29-2} ; \mathrm{S}_{7-30-1}-\mathrm{S}_{8-30-2} ; \mathrm{S}_{7-31-1}-\mathrm{S}_{8-31-2} ; \mathrm{S}_{7-32-1}-\mathrm{S}_{8-32-2}\end{array}$ & $\begin{array}{l}\text { Project owner decided not to } \\
\text { sell the object and gain the } \\
\text { value from holding }\end{array}$ \\
\hline
\end{tabular}

\section{References}

1. Dahooie, J.H.; Zavadskas, E.K.; Firoozfar, H.; Vanaki, A.; Mohammadi, N.; Brauers, W.K.M. An improved fuzzy MULTIMOORA approach for multi-criteria decision making based on objective weighting method (CCSD) and its application to technological forecasting method selection. Eng. Appl. Artif. Intell. 2019, 79, 114-128. [CrossRef]

2. Belay, A.M.; Torp, O. Do Longer Projects Have Larger Cost Deviation Than Shorter Construction Projects? Procedia Eng. 2017, 196, 262-269. [CrossRef]

3. Çelik, T.; Kamali, S.; Arayici, Y. Social cost in construction projects. Environ. Impact Assess. Rev. 2017, 64, 77-86. [CrossRef]

4. Šostak, O.R.; Vakrinien, S. Mathematical modelling of dispute proceedings between investors and third parties on allegedly violated third-party rights. J. Civ. Eng. Manag. 2011, 17, 126-136. [CrossRef]

5. Omar, M.N.; Fayek, A.R. Modeling and evaluating construction project competencies and their relationship to project performance. Autom. Constr. 2016, 69, 115-130. [CrossRef]

6. Nowak, M. Defining project approach using decision tree and quasi-hierarchical multiple criteria method. Procedia Eng. 2017, 172, 791-799. [CrossRef]

7. Saam, N.J. Asymmetry in information versus asymmetry in power: Implicit assumptions of agency theory? J. Socio-Econ. 2007, 36, 825-840. [CrossRef]

8. Sha, K. Incentive strategies for construction project manager: A common agency perspective. Constr. Manag. Econ. 2019, 37, 461-471. [CrossRef]

9. Ozbakan, T.A.; Kale, S.; Dikmen, I. Exploring House Price Dynamics: An Agent-Based Simulation with Behavioral Heterogeneity. Comput. Econ. 2019, 54, 783-807. [CrossRef] 
10. Li, H.X.; Patel, D.; Al-Hussein, M.; Yu, H.; Gül, M. Stakeholder studies and the social networks of NetZero energy homes (NZEHs). Sustain. Cities Soc. 2018, 38, 9-17. [CrossRef]

11. Zhao, Z.Y.; Zhao, X.J.; Davidson, K.; Zuo, J. A corporate social responsibility indicator system for construction enterprises. J. Clean. Prod. 2012, 29, 277-289. [CrossRef]

12. Di Maddaloni, F.; Davis, K. Project manager's perception of the local communities' stakeholder in megaprojects. An empirical investigation in the UK. Int. J. Proj. Manag. 2018, 36, 542-565. [CrossRef]

13. Xu, X.; Li, C.Z.; Wang, J.; Huang, W. Collaboration between designers and contractors to improve building energy performance. J. Clean. Prod. 2019, 219, 20-32. [CrossRef]

14. Hu, X.; Chong, H.Y.; Wang, X. Sustainability perceptions of off-site manufacturing stakeholders in Australia. J. Clean. Prod. 2019, 227, 346-354. [CrossRef]

15. Soma, K.; Dijkshoorn-Dekker, M.; Polman, N. Stakeholder contributions through transitions towards urban sustainability. Sustain. Cities Soc. 2018, 37, 438-450. [CrossRef]

16. Yu, T.; Liang, X.; Shen, G.Q.; Shi, Q.; Wang, G. An optimization model for managing stakeholder conflicts in urban redevelopment projects in China. J. Clean. Prod. 2019, 212, 537-547. [CrossRef]

17. van Dijk, S.; Tenpierik, M.; van den Dobbelsteen, A. Continuing the building's cycles: A literature review and analysis of current systems theories in comparison with the theory of Cradle to Cradle. Resour. Conserv. Recycl. 2014, 82, 21-34. [CrossRef]

18. Biesenthal, C.; Clegg, S.; Mahalingam, A.; Sankaran, S. Applying institutional theories to managing megaprojects. Int. J. Proj. Manag. 2018, 36, 43-54. [CrossRef]

19. Yusof, N.; Awang, H.; Iranmanesh, M. Determinants and outcomes of environmental practices in Malaysian construction projects. J. Clean. Prod. 2017, 156, 345-354. [CrossRef]

20. Wojewnik-Filipkowska, A.; Wegrzyn, J. Understanding of Public-Private Partnership Stakeholders as a Condition of Sustainable Development. Sustainability 2019, 11, 1194. [CrossRef]

21. Hasik, V.; Escott, E.; Bates, R.; Carlisle, S.; Faircloth, B.; Bilec, M.M. Comparative whole building life cycle assessment of renovation and new construction. Build. Environ. 2019, 106218. [CrossRef]

22. Broers, W.; Vasseur, V.; Kemp, R.; Abujidi, N.; Vroon, Z. Decided or divided? An empirical analysis of the decision-making process of Dutch homeowners for energy renovation measures. Energy Res. Soc. Sci. 2019, 58, 101284. [CrossRef]

23. Santangelo, A.; Yan, D.; Feng, X.; Tondelli, S. Renovation strategies for the Italian public housing stock: Applying building energy simulation and occupant behaviour modelling to support decision-making process. Energy Build. 2018, 167, 269-280. [CrossRef]

24. Stonebraker, J.S.; Kirkwood, C.W. Formulating and solving sequential decision analysis models with continuous variables. IEEE Trans. Eng. Manag. 1997, 44, 43-53. [CrossRef]

25. Bugajev, A.; Šostak, O. An algorithm for modelling the impact of the judicial conflict-resolution process on construction investment. Sustainability 2018, 10, 182. [CrossRef]

26. Bellman, R.E.; Dreyfus, S.E. Applied Dynamic Programming; Princeton University Press: Princeton, NJ, USA, 2015.

27. Si, J.; Marjanovic-Halburd, L.; Nasiri, F.; Bell, S. Assessment of building-integrated green technologies: A review and case study on applications of Multi-Criteria Decision Making (MCDM) method. Sustain. Cities Soc. 2016, 27, 106-115. [CrossRef]

28. Kokaraki, N.; Hopfe, C.J.; Robinson, E.; Nikolaidou, E. Testing the reliability of deterministic multi-criteria decision-making methods using building performance simulation. Renew. Sustain. Energy Rev. 2019, 112, 991-1007. [CrossRef]

29. Ishizaka, A.; Labib, A. Analytic hierarchy process and expert choice: Benefits and limitations. Insight 2009, 22, 201-220. [CrossRef]

30. Keshavarz Ghorabaee, M.; Amiri, M.; Zavadskas, E.K.; Turskis, Z.; Antucheviciene, J. Stochastic EDAS method for multi-criteria decision-making with normally distributed data. J. Intell. Fuzzy Syst. 2017, 33, 1627-1638. [CrossRef]

31. Khalil, N.; Kamaruzzaman, S.N.; Baharum, M.R. Ranking the indicators of building performance and the users' risk via Analytical Hierarchy Process (AHP): Case of Malaysia. Ecol. Indic. 2016, 71, 567-576. [CrossRef] 
32. Kamaruzzaman, S.N.; Lou, E.C.W.; Wong, P.F.; Wood, R.; Che-Ani, A.I. Developing weighting system for refurbishment building assessment scheme in Malaysia through analytic hierarchy process (AHP) approach. Energy Policy 2018, 112, 280-290. [CrossRef]

33. Zheng, X.; Easa, S.M.; Yang, Z.; Ji, T.; Jiang, Z. Life-cycle sustainability assessment of pavement maintenance alternatives: Methodology and case study. J. Clean. Prod. 2019, 213, 659-672. [CrossRef]

34. Saaty, T.L. Fundamentals of Decision Making and Priority Theory with the Snalytic Hierarchy Process; RWS Publications: Pittsburgh, PA, USA; Volume 6, 2000.

35. Fuerst, F.; Warren-Myers, G. Does voluntary disclosure create a green lemon problem? Energy-efficiency ratings and house prices. Energy Econ. 2018, 74, 1-12. [CrossRef]

36. Picarelli, N. There is no free house. J. Urban Econ. 2019, 111, 35-52. [CrossRef]

37. Ahmad, T.; Aibinu, A.A.; Stephan, A.; Chan, A.P. Investigating associations among performance criteria in Green Building projects. J. Clean. Prod. 2019. [CrossRef]

38. d'Acci, L. Quality of urban area, distance from city centre, and housing value. Case study on real estate values in Turin. Cities 2019, 91, 71-92. [CrossRef]

39. Li, H.; Wei, Y.D.; Wu, Y.; Tian, G. Analyzing housing prices in Shanghai with open data: Amenity, accessibility and urban structure. Cities 2019, 91, 165-179. [CrossRef]

40. Chen, C.S.; Chiu, Y.H.; Tsai, L. Evaluating the adaptive reuse of historic buildings through multicriteria decision-making. Habitat Int. 2018, 81, 12-23. [CrossRef]

41. Waltl, S.R. Variation across price segments and locations: A comprehensive quantile regression analysis of the Sydney housing market. Real Estate Econ. 2019, 47, 723-756. [CrossRef]

(C) 2019 by the authors. Licensee MDPI, Basel, Switzerland. This article is an open access article distributed under the terms and conditions of the Creative Commons Attribution (CC BY) license (http:/ / creativecommons.org/licenses/by/4.0/). 